FITRAH Jurnal Kajian Ilmu-ilmu Keislaman

Vol. 04 No. 2 Desember 2018

e-ISSN : 2460-2345, p-ISSN: 2442-6997

Web: jurnal.iain-padangsidimpuan.ac.id/index.php/F

\title{
UPAYA GURU AKIDAH AKHLAK DALAM MEMBINA AKHLAK SISWA DI MAN 1 PADANG
}

\author{
HARVIUS \\ STAI (Sekolah Tinggi Agama Islam) Yayasan Dakwah Islamiyah \\ (Jl. Prof. Dr. Hamka, No, 16 A Lubuk Sikaping, Pasaman, Prop.Sumatera Barat) \\ e-mail: congharvius@gmail.com
}

\begin{abstract}
This research is to find the efforts of the teachers of Akidah Akhlak in guiding the students' akhlak in and out side of the classroom, to explore the problems in guiding, and to give the solution for the problems. The method of the research is descriptive qualitative with the informan are the teacher of Akidah Akhlak, the Headmaster, teachers, and students. The instruments are collecting the data by using observation, interview, and documentation. The result showed that the teachers guided the students to have good akhlak by explaining the materials well, showing the examples, avoiding the students to cheated in examination, giving advises to be serious in learning, and giving an educated punishment to the students' falsity. Outside of the classroom, the teachers give the examples, praying zuhur together, giving kultum (preaching for 7 minutes), flag ceremonial, joining for the religious activities, cooperating with all teachers. Then, the problems are less carefulness from the teachers with the parents, unwell environment, absence from joining the religious activities, and choosing ungood friends. The efforst done by the teachers are cooperated raisingly between schools, teachers, parents, and societies. The teachers give pressure for the lesson, and give attention to the akhlak of the students. The teachers also must give good examples for the students, and give advises for them who had bad akhlak, and give advices for the parents to give attention to their children not to get bad environment and bad friends in order to be good children to make their akhlak better.
\end{abstract}

Key words: efforts, teachers of akidah akhlak, and students' akhlak.

\begin{abstract}
Abstrak
Penelitian ini bertujuan untuk mengetahui upaya guru Akidah Akhlak membina akhlak di dalam, luar kelas, kendala dalam membina akhlak siswa, mengatasi hambatan pembinaan akhlak siswa. Penelitian ini penelitian lapangan. Metode yang dipakai yaitu deskriptif. Informan adalah para Guru Akidah Akhlak, Kepala Sekolah, majelis guru, siswa. Instrumen pengumpulan data observasi, wawancara, dokumentasi. Hasil yang ditemukan adalah bahwa Pembinaan akhlak dalam kelas antara lain menyampaikan materi, keteladanan, melarang siswa mencontek ketika ujian, menegur dan menasehati yang tidak serius dalam belajar serta memberi hukuman yang mendidik kepada siswa yang melakukan kesalahan. Pembinaan di luar kelas; keteladanan, sholat zuhur berjamaah, kultum di setiap Jum'at pagi, upacara bendera dan ikut serta dalam kegiatan
\end{abstract}


FITRAH Jurnal Kajian Ilmu-ilmu Keislaman

Vol. 04 No. 2 Desember 2018

keagamaan, kerja sama dengan majelis guru, pengurus sekolah. Kendala yang dihadapi; tidak adanya kerja sama guru dengan wali murid, lingkungan yang tidak baik, tidak mengikuti kegiatan keagamaan dan salah dalam memilih teman bergaul. Cara mengatasinya adalah peningkatan kerja sama antara pihak sekolah dengan orang tua dan masyarakat, Guru Akidah Akhlak agar memberikan penekanan terhadap materi pelajaran Akidah Akhlak dan selalu memperhatikan perkembangan akhlak siswa, kepada seluruh guru agar memberikan keteladanan yang baik dan selalu menegur dan menasehati yang melakukan akhlak yang tidak baik dan orang tua agar selalu memperhatikan perkembangan dan pergaulan anaknya supaya tidak terpengaruh pada lingkungan yang tidak baik.

Kata Kunci: Upaya, Guru Akidah Akhlak, Akhlak Siswa

\section{PENDAHULUAN}

Pendidikan agama di madrasah harus mampu menjawab berbagai tantangan yang lahir baik dari dalam (internal) yang menyangkut dengan program pengajaran agama sebagai sisi pendidikan dan tantangan yang datang dari luar (eksternal) yang menyangkut dengan berbagai kemajuan ilmu pengetahuan dan teknologi serta tuntutan dunia lapangan kerja. Pendidik merupakan satu di antara komponen pendidikan mempunyai peranan yang sangat penting dalam mencapai tujuan tersebut di atas. Karena pembelajaran berlangsung sebagai suatu proses yang saling mempengaruhi antara guru dan siswa. Pendidik mengajar di satu pihak dan siswa belajar pada pihak lain.

Pendidik bukanlah suatu pekerjaan yang mudah. Mengajar memerlukan kesiapan mental yang memadai agar dapat melaksanakan kegiatan tersebut dengan baik. Di samping harus menguasai bahan guru juga harus memahami karakteristik peserta didik itu sendiri. Guru tidak hanya bertugas menyampaikan bahan di depan kelas tapi juga menyiapkan dan mendesain bahan pelajaran, memberikan tugas-tugas, melaksanakan kegiatan penunjang lainnya. Satu hal yang sangat penting bagi guru adalah memahami keadaan siswanya.

Dalam Sistem Pendidikan Nasional dan Undang-Undang Guru dan Dosen mengatakan bahwa guru adalah pendidik profesional dengan tugas utama mendidik, mengajar, membimbing, mengarahkan, melatih, menilai, dan mengevaluasi peserta didik pada pendidikan usia dini jalur pendidikan formal, pendidikan dasar, dan menengah". ${ }^{1}$ Guru mempunyai banyak arti dan tanggung

1 Departemen Agama. Direktorat Jenderal Pendidikan Islam, Undang-undang Republik Indonesia Nomor 14 Tahun 2005 tentang Guru dan Dosen (Bandung: Citra Umbara, 2006), hlm. 60, https://books.google.co.id/books?id=87DFmgEACAAJ\&dq=Undang- 
jawab dalam mengayomi peserta didiknya agar ilmu yang diajarkannya dapat dipergunakan oleh peserta didiknya dalam kehidupan sehari-hari.

Di antara faktor pendidikan yang sangat berperan adalah seorang guru atau pendidik. Menurut pengertian yang sederhana, guru adalah orang yang memberikan ilmu pengetahuan kepada peserta didik. Guru dalam pandangan masyarakat adalah orang yang melaksanakan pendidikan di tempat - tempat tertentu, tidak mesti di lembaga pendidikan formal, tetapi bisa juga di masjid, di surau, rumah dan sebagainya.

Peran aktif seorang guru dalam pencapaian tujuan pendidikan nasional sangat dibutuhkan. Guru yang mempunyai tanggung jawab dalam menanamkan nilai-nilai iman dan taqwa kepada peserta didik agar peserta didik itu memiliki keimanan dan ketaqwaan kepada Allah Yang Maha Kuasa, sehat jasmani dan rohani serta berbudi pekerti luhur. Hal itu sesuai dengan tujuan Pendidikan agama Islam yaitu untuk mendidik anak menjadi muslim sejati, beriman dan beramal saleh, berakhlak mulia, berguna bagi masyarakat, bangsa dan Negara. Sebagaimana pendapat Al-Ghazali dikutip oleh Abidin Ibnu Rusd bahwa: "Pendidikan Islam mengarahkan kepada pembentukan insan kamil, yakni khalifah pada hakikatnya manusia saleh". ${ }^{2}$

Pembinaan akhlak dapat dilakukan dalam proses pembelajaran maupun di luar proses pembelajaran. Pihak-pihak sekolah yang terkait dalam pendidikan akhlak atau pembinaan tingkah laku ini adalah pimpinan sekolah, guru-guru dan pihak sekolah lainnya. Pembinaan akhlak ini dapat dilakukan dengan beberapa cara: ${ }^{3}$

1. Pimpinan sekolah, guru-guru dan pihak sekolah lainnya hendaknya memberikan contoh teladan yang baik (uswatun hasanah) dalam mengamalkan ajaran agama, seperti dalam melaksanakan ibadah shalat, menjalin tali persaudaraan, memelihara kebersihan, mengucapkan dan menjawab salam, bersemangat dalam menuntut ilmu, dan berpakaian sesuai aturan agama.

undang+RI+No.14+Tahun+2005+Tentang+Guru+dan+Dosen\&hl=en\&sa=X\&ved=0ahUKEwiT8dekq M7fAhXadCsKHcS6CI4Q6AEIKTAA.

2 Abidin Ibnu Rusn, Pemikiran Al-Ghazali tentang pendidikan (Yogyakarta: Pustaka Pelajar,

1998), hlm. 133, https://books.google.co.id/books?id=bp5HAgAACAAJ\&dq=Abidin+Ibnu+Rusd,+Pemikiran+AlGhazali+Tentang+Pendidikan\&hl=en\&sa=X\&ved=0ahUKEwjCkbX9qM7fAhWJMI8KHZ5GB5AQ6 AEIKzAA.

3 H. Syamsu Yusuf LN, Psikologi perkembangan anak \& remaja (Bandung: Remaja Rosdakarya, 2000), hlm. 36, https://books.google.co.id/books?id=kaEAAAACAAJ\&dq=Syamsu+Yusuf + LN\&hl=en\&sa=X\&ved=0ahUKEwibyOitqc7fAhUOaI8KHQtmD PIQ6AEILDAA. 
FITRAH Jurnal Kajian Ilmu-ilmu Keislaman

Vol. 04 No. 2 Desember 2018

2. Guru-guru yang mengajar bidang studi umum hendaknya menginternalisasikan nilai-nilai agama termasuk akhlak ke dalam materi pelajaran yang diajarkannya.

3. Pihak sekolah hendaknya menyelenggarakan kegiatan ekstrakurikuler kerohanian bagi para siswa dan ceramah-ceramah atau diskusi keagamaan secara rutin terutama yang menyangkut akhlak.

Orang yang memiliki akidah atau keimanan yang baik akan memiliki akhlak yang baik pula, yang dapat terlihat pada tingkah lakunya. Sehubungan dengan penanaman iman ini, ada beberapa usaha yang dapat dilakukan oleh kepaala sekolah, guru maupun aparat sekolah lainnya: ${ }^{4}$

1. Memberikan contoh atau teladan.

2. Pembiasaan terhadap segala yang baik untuk dilakukan.

3. Menegakkan disiplin, yang sebenarnya merupakan bagian dari pembiasaan.

4. Memberikan motivasi atau dorongan.

5. Memberikan hadiah, terutama psikologis.

6. Menghukum dalam rangka pendisiplinan.

7. Menciptakan suasana yang berpengaruh positif, yakni berkaitan dengan penumbuhan keimanan.

Hal di atas merupakan beberapa gambaran usaha yang dapat dilakukan oleh semua pihak sekolah untuk pembinaan tingkah laku siswa. Usaha-usaha tersebut akan berhasil jika seluruh pihak sekolah bekerjasama dalam mewujudkannya.

Kajian penelitian yang ada relevansinya dengan penelitian ini dapat dikemukakan sebagai berikut: Selamat Ariga. ${ }^{5}$ Tesis: dalam penelitian yang berjudul pendidikan akhlak anak dalam keluarga pedagang di kelurahan dadok tunggul hitam kecematan koto tangah. Kajian yang terdapat dalam penelitian ini lebih menekan tentang pentingnya peran yang harus dilaksanakan oleh keluarga pedagang terhadap anak. Penelitian ini mengahasilkan bahwa keluarga pedagang belum memiliki akhlak yang baik karena orang tua sibuk mencari nafkah atau berdagang di pasar.

\footnotetext{
${ }^{4}$ Ahmad Tafsir, Metodologi pengajaran agama Islam (Bandung: Remaja Rosdakarya, 1999), hlm. 127, https://books.google.co.id/books?id=3VUAgAACAAJ\&dq=Ahmad+Tafsir.+Metodologi+Pengajaran+Agama\&hl=en\&sa=X\&ved=0ahUKE wi19pGJq87fAhUFqY8KHSeoAYMQ6AEIKTAA.

5 Selamat Ariga, "Pendidikan Akhlak Anak Dalam Keluarga Pedagang Di Kelurahan Dadok Tunggul Hitam Kecematan Koto Tangah" (Tesis Sarjana Pendidikan, PPs IAIN Imam Bonjol Padang, 2010).
} 
Dewi Yulian ${ }^{6}$ Tesis: Dalam penelitian yang berjudul usaha pembinaan akhlak siswa di SMP Negeri 2 padang. Penelitian ini lebih menekankan tentang usaha pembelajaran pendidikan agama islam dan kegiatan ektrakurikuler keagamaan dalam pembinaan akhlak siswa SMP 2 Padang. Penelitian ini menyimpulkan bahwa siswa siswi SMP 2 Padang memiliki kemampuan kognitif sangat baik karena dilihat prestasi-prestasi yang diperoleh, namun akhlak belum baik.

\section{METODOLOGI PENELITIAN}

Penelitian ini adalah penelitian lapangan (field research). Informasi diperoleh melalui informan atau responden melalui instrumen pengumpulan data seperti angket, wawancara, observasi dan sebagainya. ${ }^{7}$ Penelitian ini dilakukan di Madrasah Aliyah Negeri (MAN) 1 Padang yang letaknya di Jl. Durian Tarung Kelurahan Pasar Ambacang kota Padang. Penelitian ini dilaksanakan dengan survey, observasi dan studi dokumentasi, penggalian informasi data secara komprehensif. Data primernya adalah Guru Akidah Akhlak Madrasah Aliyah Negeri 1 Padang. Sedangkan data skundernya adalah kepala sekolah, majelis guru dan siswa-siswi MAN 1. Pengumpulan data dilakukan dengan Metode observasi (participant observation), ${ }^{8}$ wawancara dengan para guru, kepala sekolah dan siswa, ${ }^{9}$ dan Studi Dokument. ${ }^{10}$ Studi dokumentasi ini untuk memperoleh data tentang profil Sekolah Madrasah Aliyah Negeri 1 Padang yang meliputi upaya Guru Akidah Akhlak dalam membina akhlak siswa di MAN 1 Padang. Untuk menguji kebasahan data dalam penelitian ini, penulis melakukan uji cedibility (validitas internal), tranferabilty (validitas eksternal), dependability (reliabilitas), dan confirmabiliy (objektivitas.

${ }^{6}$ Dewi Yulian, "Usaha Pembinaan Akhlak Siswa Di Smp Negeri 2 Pada” (Tesis Sarjana Pendidikan, PPs IAIN Imam Bonjol Padang, 2013).

${ }^{7}$ Abudin Nata, Metodologi Studi Islam (Jakarta: Raja Grapindo Persada, 2004), hlm. 125.

${ }^{8}$ Lexy J Moleong, Metodelogi Penelitan Kualitatif (Bandung: Remaja Rosdakarya, 2000), hlm. 125-126.

9 Nana Syaodih Sukmadinata, Metode penelitian pendidikan (Bandung: Program Pascasarjana Universitas Pendidikan Indonesia dengan PT Remaja Rosdakarya, 2005), hlm. 216, https://books.google.co.id/books?id=qXxjAQAACAAJ\&dq=Nana+Syaodih+Sukmadinata,+Metodol ogi+Penelitian+Pendidikan\&hl=en\&sa=X\&ved=0ahUKEwjC7qzjrM7fAhUaWX0KHY1AgkQ6AEIKTAA.

${ }^{10}$ Suharsimi Arikunto, Prosedur Penelitian: Suatu Pendekatan Praktik (Jakarta: Rineka Cipta, 2013), hlm. 231. 
FITRAH Jurnal Kajian Ilmu-ilmu Keislaman

Vol. 04 No. 2 Desember 2018

\section{HASIL DAN PEMBAHASAN}

\section{Upaya Guru Akidah Akhlak Membina Akhlak Siswa di dalam Kelas di MAN \\ I Padang}

a. Menyampaikan materi/bahan ajar tentang akidah akhlak

Materi yang disampaikan oleh guru akidah akhlak MAN 1 Padang berjalan dengan baik. Hal ini terbukti ketika akan memulai pelajaran guru terlebih dahulu harus menjelaskan Standar Kompetensi, Kompetensi Dasar, Indikator Pembelajaran dan Tujuan Pembelajaran yang akan dicapai dari setiap materi yang diajarkan. ${ }^{11}$

Sejalan dengan hasil wawancara dengan guru akidah akhlak bahwa ketika akan memulai pelajaran guru menjelaskan Standar Kompetensi, Kompetensi Dasar, Indikator Pembelajaran dan Tujuan Pembelajaran yang akan dicapai pada tiap materi yang akan dibahas, dan ketika akan memulai pelajaran guru terlebih dahulu memberitahukan atau mengenalkan materi yang akan dipelajari siswa/siswi supaya siswa merasa tertarik dengan pelajaran yang akan dibahas. ${ }^{12}$

Kepala sekolah menyatakan: "Penyampaian materi mata pelajaran akidah akhlak itu cukup efektif dalam pembinaan akhlak sebagian besar siswa. Karena, dalam mata pelajaran tersebut mengandung nilai-nilai akhlak dan iman. Nilai-nilai inilah yang akan diinternalisasikan melalui kognitif siswa, yang akan tertanam dalam afektifnya, sehingga terlihat pelaksanaannya pada psikomotoriknya, yakni, pada tingkah lakunya."13

Berdasarkan hasil wawancara dengan guru MAN 1 Padang, menerangkan bahwa sebelum melaksanakan pembelajaran terlebih dahulu guru akidah akhlak MAN 1 Padang membuat, menyesuaikan pembelajarannya dengan silabus dan mempersiapkan alat atau bahan yang sesuai dengan materi yang hendak diajarakan. Misalnya dalam pelajaran Akidah akhlak, mereka menyiapkan buku akidah akhlak, buku-buku yang relevan dengan materi, dan mereka juga menggunakan alat peraga berupa gambar atau benda-benda lainnya, misalnya dalam pelajaran mengenai akhlak sesama manusia yaitu mempersiapkan media. ${ }^{14}$

Hal ini sesuai dengan wawancara dengan kepala sekolah bahwa “Setiap guru Akidah Akhlak di sekolah ini membuat RPP, silabus masing-

\footnotetext{
${ }^{11}$ Fitriyani, Guru MAN I Padang, Wawancara, Padang, 29 November 2013

12 Arifin, Guru MAN I Padang, Wawancara, Padang, 29 November 2013

${ }^{13}$ Marliza, Kepala sekolah MAN I Padang, Wawancara, Padang, 29 November 2013

${ }^{14}$ Fitriyani, Guru MAN I Padang, Wawancara, Padang, 29 November 2013
} 
masing. Kemudian, mereka menerapkan silabus tersebut ke dalam pembelajaran Akidah Akhlak."15

Dalam kesempatan lain, peneliti mengadakan wawancara dengan salah satu guru alquran hadist, Guru tersebut menyatakan: "Guru Akidah Akhlak yang berada di sekolah ini mempunyai RPP, silabus. Mereka berdua menggunakannya untuk pelaksanaan pembelajaran Akidah Akhlak di dalam kelas." 16

Hasil wawancara penulis dengan siswa-siswi MAN 1 Padang mengatakan bahwa: guru akidah akhlak dalam melakukan pembinaan akhlak maka guru menyampaikan materi atau bahan ajar tentang akidah akhlak. Guru menguraikan tentang akhlak kepada Allah, Rasulullah, atau menjelaskan rukun iman, akhlak sesama manusia, akhlak terhadap alam atau lingkungan sekitarnya. ${ }^{17}$

Dalam pembinaan akhlak siswa di MAN 1 Padang, guru sering memberikan materi yang berkaitan dengan hal yang dapat membentuk akhlak. Guru menjelaskan tujuan pembelajaran yang hendak dicapai dalam setiap pembahasan. Misalnya untuk membentuk kepribadian siswa dalam hal beribadah guru memberikan materi berupa: iman kepada Allah, memperkenalkan sifat-sifat Allah, Asmaul Husna,menjelaskan tentang rukun Islam dan rukun iman. ${ }^{18}$

Senada dengan hal di atas guru akidah akhlak mengatakan bahwa untuk membentuk akhlak muslim siswa dalam hal berkomunikasi guru memberikan materi tentang pengabdian yang meliputi pengabdian kepada Allah, pengabdian kepada orang tua, pengabdian kepada masyarakat, selanjutnya mengajarkan tentang bagaimana cara berbakti terhadap kedua orang tua, menanamkan akhlak mulia kepada anak didik, mengajarkan tentang sikap terhadap tetangga, menjaga hubungan persaudaraan, bersikap adil, pemurah bersahaja dan cermat, selalu berdakwah pada kebaikan dan membudayakan ucapan salam di lingkungan sekolah dan di luar lingkungan sekolah, menganjurkan kepada siswa supaya selalu bertutur kata yang sopan kepada orang lain. ${ }^{19}$

b. Keteladanan

1) Mengucapkan salam ketika memasuki ruangan kelas

\footnotetext{
${ }^{15}$ Marliza, Kepala sekolah MAN I Padang, Wawancara, Padang, 30 November 2013

${ }^{16}$ M.Nasir Sarim, Guru MAN I Padang, Wawancara, Padang, 29 November 2013

${ }^{17}$ Muhammad Sukri, siswa MAN 1 Padang, wawamcara,29 November 2013

${ }^{18}$ Fitriyani, Guru MAN I Padang, Wawancara, Padang, 3 Desember 2013

${ }^{19}$ Fitriyani, Guru MAN I Padang, Wawancara, Padang, 3 Desember 2013
} 
FITRAH Jurnal Kajian Ilmu-ilmu Keislaman

Vol. 04 No. 2 Desember 2018

Para guru Akidah Akhlak telah melaksanakan hal ini dengan baik, hal ini sebagaimana hasil wawancara penulis dengan salah satu guru Akidah Akhlak, ia mengatakan: “Sebagai guru Akidah Akhlak saya selalu mengucapkan salam ketika memasuki ruangan kelas, ini saya lakukan karena dianjurkan oleh agama Islam di samping itu juga merupakan salah satu cara saya membudayakan salam kepada peserta didik, agar mereka terbiasa mengucapkan salam di dalam kehidupan mereka seharihari". ${ }^{20}$

Kemudian dari pernyataan guru akidah akhlak MAN 1 Padang, diperkuat oleh guru Alquran Hadist yang mengatakan bahwa: " seorang guru harus mampu menjadi contoh di hadapan perserta didik dalam segala hal, termasuk sebelum memasuki ruangan belajar guru mampu mengucapkan salam. ${ }^{21}$

Sebagaimana hasil wawancara dengan siswa MAN 1 Padang juga mengatakan bahwa: ketika memasuki lokal guru-guru mengucapkan salam kepada siswa-siswi MAN 1 Padang, ini merupakan bukti bahwa guru-guru menberikan contoh yang baik dihadapan siswa. Begitu pula halnya, ketika keluar dari ruangan belajar guru-guru juga mengucapkan salam. $^{22}$

Hasil wawancara yang penulis lakukan di atas juga didukung oleh hasil observasi yang dilakukan. Dari hasil observasi yang penulis lakukan pada tanggal 3 Desember 2013 terlihat bahwa seluruh guru Akidah Akhlak telah melaksanakan dengan baik budaya mengucapkan salam ketika memasuki ruangan kelas. Dari hasil observasi juga terlihat bahwa guru Akidah Akhlak bukan saja di waktu memasuki ruangan kelas mengucapkan salam, tetapi disaat mereka meninggalkan ruangan kelas mereka juga mengucapkan salam. ${ }^{23}$

2) Memakai pakaian yang menutup aurat sewaktu mengajar

Hasil wawancara penulis dengan salah seorang guru Akidah Akhlak ia mengatakan : "Selaku guru Akidah Akhlak saya selalu berusaha berpakaian yang bisa memberikan contoh kepada peserta didik saya, terutama kepada siswi-siswi saya. Di samping itu saya juga selalu memeriksa pakaian mereka terutama baju yang terlalu kecil atau sempit

${ }^{20}$ Fitriyani, Guru MAN I Padang, Wawancara, Padang, 3 Desember 2013

${ }^{21}$ M. Nasir Sarim, Guru MAN 1 Padang, wawancara, Padang 3 Desember 2013

${ }^{22}$ Muhammad sukri, siswa MAN 1 Padang, wawancara, Padang, 3 Desember 2013

${ }^{23}$ Observasi tentang pembinaan akhlak siswa di MAN 1 Padang, 3 Desember 2013 
dan jilbab yang tidak betul dalam pemakaiannya, seperti memakai jilbab dengan rambut yang keluar". ${ }^{24}$

Hal yang senada juga dikemukakan oleh guru lain, ia mengemukakan:"Pada saat sekarang banyak peserta didik yang terpengaruh oleh budaya yang sedang berkembang, terutama dari segi berpakaian. Bagi siswa yang laki-laki banyak yang memakai celana sekolah yang kakinya kecil ke bawah atau celana pensil. Dan bagi siswa yang perempuan sering ditemukan memakai jilbab dan rok yang terlalu banyak gayanya. Untuk mengatasi hal ini saya selalu memberi contoh yang baik dalam berpakaian dan sebelum belajar saya memeriksa mereka yang berpakaian tidak sesuai dengan peraturan sekolah tersebut" ${ }^{25}$

Lebih lanjut, Kepala MAN 1 Padang juga mengungkapkan bahwa: Saya selaku kepala sekolah atau pucuk pimpinan di MAN 1 Padang, saya harus mampu berpakaian rapi, bersih, tidak ketat, tipis dan menutup aurat agar perserta didik bisa mampu mencontohkannya, bagi perserta didik yang berpakaian ketat atau yang tidak berpakaian sesuai dengan aturan MAN 1 Padang, maka saya akan memanggilnya, memberikan pembinaan kepadanya. Setelah diberikan pembinaan kepada siswa-siswi yang melanggar berpakaian maka saya menberikan hukuman, ganjaran yang mendidik. ${ }^{26}$

Keterangan dari guru-guru dan kepala sekolah, maka saya menyimpulkan bahwa guru-guru harus mampu menjadi uswah dalam berpakaian karena akan pengaruh yang baik terhadap peserta didik. Disamping itu siswa-siswi bisa mencontohkannya dalam berpakaian yang telah ditetapkan dalam aturan berpakaian di MAN 1 Padang.

3) Berbicara dengan sopan-santun sewaktu mengajar Hasil wawancara dengan guru MAN 1 Padang, mengatakan:“Dalam menyampaikan pelajaran selaku guru Akidah Akhlak tentunya saya sangat berhati-hati sekali, karena semua pembicaraan yang keluar dari mulut seorang guru Akidah Akhlak biasanya akan menjadi pedoman oleh peserta didik. Begitu juga dalam menasehati dan menegur peserta didik yang bermasalah dalam belajar, harus dinasehati dengan baik dan penuh kelembutan" ${ }^{27}$

\footnotetext{
${ }^{24}$ Arifin, Guru MAN I Padang, Wawancara, Padang, 3 Desember 2013

${ }^{25}$ Armayanti, MAN I Padang, Wawancara, Padang, 3 Desember 2013

26Marliza, kepala MAN 1 Padang, wawancara, Padang, 3 Desember 2013

27fitriyani, Guru MAN I Padang, Wawancara, Padang, 3 Desember 2013
} 
FITRAH Jurnal Kajian Ilmu-ilmu Keislaman

Vol. 04 No. 2 Desember 2018

Informasi yang senada juga diungkapkan oleh salah seorang guru MAN 1 Padang bahwa: "saya selaku guru harus mampu menyampaikan materi pelajaran dengan bahasa yang baik, lemah lembut, yang mudah dipahami dan tidak berkata-kata kasar agar peserta didik mengerti dan senang mengikuti pelajaran". ${ }^{28}$

Berdasarkan observasi penulis lakukan bahwa terlihat guru-guru menyampaikan berkata kata yang baik sesama majelis guru, disamping itu juga berkata-kata baik kepada peserta didik. ${ }^{29}$

4) Membiasakan membaca Basmalah, doa ketika memulai belajar dan Hamdalah ketika selesai belajar

Wawancara yang penulis lakukan terhadap guru MAN 1 Padang, mengungkapkan bahwa: " sebelum proses belajar mengajar dimulai maka saya mengawalinya dengan membaca doa, setelah itu dilanjutkan dengan membaca ayat suci alquran yang baca oleh salah satu siswa yang telah ditunjuk dan siswa-siswi lainnya menyimak dengan baik. setelah belajar maka diakhiri dengan mengucapkan kalimat hamdalah. ${ }^{30}$

Hasil wawancara degan siswi MAN 1 Padang, juga mengungkapkan bahwa: "guru-guru sebelum menyampaikan materi ajarnya kepada siswa, maka terlebih dahulu guru mengawali dengan membaca kalimat basmalah dan diakhiri dengan hamdalah, agar lebih lancar dalam proses belajar mengajar dan bernilai ibadah. ${ }^{31}$ "

5) Tidak membeda-bedakan siswa dalam belajar

Dari hasil wawancara dengan salah seorang guru Akidah Akhlak,mengungkapkan: “Dalam memberikan pelajaran saya tidak membeda-bedakan antara peserta didik yang satu dengan yang lainnya. Saya menganggap mereka adalah sama, yaitu seorang manusia yang mempunyai berbagai macam kelebihan dan kekurangan. Dengan menyadari mereka seperti ini saya sebagai guru mempunyai kewajiban untuk mendidik mereka dengan memberikan kasih sayang yang sama sehingga mereka merasa tidak di beda-bedakan" ${ }^{32}$

Keteladanan yang diberikan oleh Guru Akidah Akhlak dalam membina akhlak siswa di MAN I Padang di lakukan dengan cara:

a) Bentuk yang disengaja

${ }^{28}$ Muharni, Guru MAN 1 Padang, Wawancara, Padang, 3 Desember 2013

${ }^{29}$ Observasi tentang pembinaan akhlak siswa di MAN 1 Padang, 3 Desember 2013

${ }^{30}$ fitriyani, Guru MAN I Padang, Wawancara, Padang, 3 Desember 2013

${ }^{31}$ Suci Pramita, siswa MAN 1 Padang, wawancara, Padang, 3 Desember 2013

32fitriyani, Guru MAN I Padang, Wawancara, Padang, 3 Desember 2013 
Dalam memberikan contoh teladan kepada peserta didiknya guru Akidah Akhlak MAN I Padang telah menerapkannya dengan disengaja, hal ini mereka lakukan agar peserta didik senantiasa meniru apa yang telah mereka contohkan tersebut. Adapun bentuk keteladanan yang diberikan secara sengaja tersebut yaitu seperti mengajarkan anak membaca Al-Qur'an yang baik sewaktu belajar, memberikan contoh tentang kisah-kisah teladan kepada peserta didik dengan tujuan mereka dapat belajar dan menjadikan kisah-kisah tersebut sebagai pedoman bagi mereka dalam berbuat dan bertindak dalam kehidupan sehari-hari.

b) Tidak disengaja

Hasil wawancara dengan guru MAN 1 Padang, ia mengungkapkan: "Selaku guru Akidah Akhlak secara spontan dan tidak ada niat sengaja sebelumnya menasehati siswa yang mencontek ketika ujian karena siswa mencontek ketika ujian saya menasehatinya," ${ }^{33}$

Begitu pula halnya dengan guru yang lain juga senada mengatakan bahwa:" bagi siswa-siswi yang tidak ada membuat tugas sekolah, maka saya secara spontan menasehati agar siswa-siswi dapat tugasnya dengan baik. Pembinaan ini dilakukan tidak ada niat saya untuk menasehatinya karena ada siswa yang tidak mengerjakannnya maka saya selaku guru memberikan pembinaan terhadapnya. ${ }^{34}$

Berdasarkan observasi yang penulis lakukan bahwa saya melihat kepala sekolah MAN 1 Padang memberikan teguran spontan kepada siswa-siswi yang membuang sampah tidak pada tempatnya. Tujuannnya adalah agar peserta didik bisa membiasakan diri membuang sampah pada tempatnya dan menjaga kebersihan lingkungannya. ${ }^{35}$

6) Melarang siswa mencontek ketika ujian atau ulangan

Guru akidah akhlak mengungkapkan: "Salah satu usaha yang dilakukan guru Akidah Akhlak dalam membina rasa kepercayaan diri dan kejujuran peserta didik adalah dengan melarang dan menegur siswa melihat atau mencontoh jawaban teman mereka ketika ulangan atau ujian. Di saat ulangan atau ujian saya selalu mengawasi mereka dengan baik agar mereka dapat mengerjakannya dengan sendiri dan tidak mencontoh jawaban teman mereka". ${ }^{36}$

${ }^{33}$ Arifin, Guru MAN I Padang, Wawancara, Padang, 3 Desember 2013

${ }^{34}$ Muhammad Nasir Sarim, Guru MAN I Padang, Wawancara, Padang, 3 Desember 2013

${ }^{35}$ Observasi tentang pembinaan akhlak siswa di MAN 1 Padang, 3 Desember 2013

36Fitriyani, Guru MAN I Padang, Wawancara, Padang, 3 Desember 2013 
FITRAH Jurnal Kajian Ilmu-ilmu Keislaman

Vol. 04 No. 2 Desember 2018

Lebih lanjut, guru MAN 1 Padang lainya juga mengungkapkan bahwa: " saya selaku guru menyampaikan kepada siswa agar jujur berkata dan berbuat, termasuk dalam hal ketiaka ujian agar tidak melihat lembar jawaban teman, mencontek dan tidak membawa buku catatan. ${ }^{37}$

7) Menegur dan menasehati siswa yang tidak serius dalam belajar

Berdasarkan wawancara penulis dengan guru akidah akhlak mengatakan bahwa:" saya selaku guru akidah akhlak selalu memberikan nasehat kepada siswa-siswi yang tidak serius mengikuti pelajaran, karena tanpa keseriusan dari siswa-siswi maka tidak akan dapat memahmi pelajaran. Tujuan saya adalah agar peserta didik mengerti dengan pelajaran yang diberikan, disamping itu juga saya berharap siswa-siswi mendapatkan nilai yang baik. ${ }^{38}$

8) Memberikan hukuman yang mendidik kepada siswa yang berbuat kesalahan dalam belajar

Hasil wawancara dengan salah seorang guru, mengungkapkan: “Dalam proses belajar mengajar biasanya ada saja siswa yang berbuat kesalahan, seperti ribut dan mengambil barang atau alat milik teman mereka. Untuk mengatasi hal ini saya selaku guru berusaha menasehati dengan baik, apabila tidak ada perubahan pada diri anak tersebut jalan terakhir yaitu memberikan hukuman yang mendidik kepada mereka seperti menyuruh ia mengganti barang temannya yang telah ia ambil “. ${ }^{39}$

\section{Upaya yang dilakukan Guru Akidah Akhlak dalam Membina Akhlak Siswa di Luar Kelas di MAN I Padang}

1. Keteladanan

Para guru Akidah Akhlak telah melakukan beberapa cara dalam memberikan keteladanan kepada siswa dalam rangka pembinaan akhlak siswa di luar kelas. Adapun cara-cara yang mereka lakukan tersebut sebagai berikut:

a. Sopan-santun dengan sesama guru

Dalam pergaulan antara sesama guru kadang kala sering terjadi tindakan atau perbuatan yang tidak baik dari seorang guru. Salah satu contoh adalah dalam berbicara dan bersenda gurau dengan sesama guru. Dengan asyiknya bercerita dan bersenda gurau terkadang sering terucap

${ }^{37}$ Arifin, Guru MAN I Padang, Wawancara, Padang, 3 Desember 2013

${ }^{38}$ Fitriyani, Guru MAN I Padang, Wawancara, Padang, 3 Desember 2013

${ }^{39}$ Armayanti, Guru MAN I Padang, Wawancara, Padang, 3 Desember 2013 
kata-kata yang kurang baik. Apabila perbuatan ini di dengar oleh peserta didik maka akan menjadi tidak baik bagi seorang guru. Hal ini karena biar bagaimanapun juga guru harus senantiasa mengawasi perbuatannya agar tidak menyimpang ke hal-hal yang kurang baik.

Hal tersebut sangat disadari oleh guru Akidah Akhlak di MAN I Padang, mereka selalu berusaha agar segala perbuatan dan tindakannya selalu dapat memberikan contoh teladan yang baik bagi peserta didiknya. Guru MAN 1 Padang menjelaskan sebagai berikut: “Dalam memberikan contoh teladan yang baik, saya selalu berusaha berbuat dan bertindak terutama dalam pergaulan dengan sesama guru dengan pergaulan yang baik. hal ini menurut saya sangat penting sekali karena terkadang tanpa disadari peserta didik selalu mengamati dan memperhatikan bagaimana sebagai seorang guru bertingkah laku dengan sesama guru". ${ }^{40}$

b. Sopan-santun dengan Pimpinan

Hasil wawancara dengan guru akidah akhlak mengunkapkan: "Apabila antara pimpinan dan staf dapat saling menjaga hubungan dengan baik, maka akan tecipta suasana yang baik dalam suatu sekolah. Selaku guru Akidah Akhlak menyadari hal itu, karena ia menyadari bahwa semua gerak- gerik dan perbuatannya merupakan sesuatu yang akan senantiasa menjadi diperhatikan dan dicontoh oleh peserta didik". ${ }^{41}$

c. Berakhlak baik kepada siswa

Hasil wawancara dengan guru lain mengunkapkan: "saya selaku guru akidah akhlak harus bisa menanamkan bahwa peserta didik adalah bagian dari hidupnya. Dengan seperti ini guru akan merasa bertanggung jawab penuh terhadap peserta didiknya. Di samping itu ia juga harus bisa menempatkan dirinya sebagai sosok yang selalu melindungi peserta didiknya dengan penuh kasih sayang. Bergaul dengan peserta didiknya sebagaimana ia bergaul dengan anak mereka sendiri" ${ }^{42}$

Hasil wawanacara dengan siswa MAN 1 Padang,mengatakan bahwa:" saya merasakan selama sekolah di MAN 1 Padang, majelis guru MAN 1 Padang memilik akhlak yang baik, ramah, sopan terhadap siswisiswinya. Saya sangat kagum terhadap guru-guru yang memilik akhlak yang baik, sehingganya saya harus bisa juga memiliki akhlak yang baik terhadap teman. ${ }^{43}$

${ }^{40}$ Fitriyanti, GuruMAN I Padang, Wawancara, Padang, 4 Desember 2013

${ }^{41}$ Arifin, GuruMAN I Padang, Wawancara, Padang, 4 Desember 2013

42Armayanti, Guru MAN I Padang, Wawancara, Padang, 4 Desember 2013

${ }^{43}$ Suci Pramita, siswa MAN 1 Padang, wawancara, Padang, 4 Desember 2013 
FITRAH Jurnal Kajian Ilmu-ilmu Keislaman

Vol. 04 No. 2 Desember 2018

d. Berusaha berakhlak yang mulia

Berdasarkan wawancara penulis dengan guru akidah akhlak mengatakan bahwa:" saya harus mampu memiliki akhlak yang baik dan setiap gerak gerik yang akan saya lakukan saya harus hati-hati karena akan di tiru oleh siswa-siswi. ${ }^{44}$

Guru Akidah Akhlak telah melakukan berbagai cara dalam memberikan keteladanan kepada siswa di luar kelas. Cara-cara tersebut yaitu: selalu menjaga sopan-santun dalam bergaul dengan sesama guru, bersopan-santun dengan atasan, berakhlak yang baik dan mulia kepada siswa dan selalu berusaha berakhlak yang baik di sekolah, di rumah dan di tengah masyarakat.

2. Shalat Zuhur berjama'ah

Kegiatan shalat zuhur berjama'ah dilakukan setiap hari sekolah. Hal ini terlihat dari observasi yang penulis lakukan bahwa kegiatan ini diikuti oleh seluruh siswa mulai dari kelas satu hingga kelas tiga. Dalam kegiatan ini guru Akidah Akhlak ikut serta dalam mengatur pelaksananan shalat berjama'ah ini. Adapun hal yang diatur dalam pelaksanaannya yaitu menunjuk secara langsung siapa siswa yang muadzin. ${ }^{45}$

Hasil wawancara dengan Guru MAN 1 Padang, salah seorang guru Akidah Akhlak mengungkapkan: "Sekolah telah mewajibkan kepada seluruh siswa untuk melaksanakan shalat zuhur berjama'ah. Shalat zuhur berjama'ah ini diwajibkan oleh sekolah sebagai salah satu cara atau usaha yang dilakukan agar peserta didik terbiasa melaksanakan shalat berjama'ah dan shalat tepat pada waktunya". ${ }^{46}$ Dalam pelaksanaan kegiatan shalat zuhur ini sangatlah baik karena dengan ini akan membiasakan murid melaksanakan shalat berjama'ah dan melaksanakan shalat tepat pada waktunya.

3. Kultum setiap Jum'at pagi

Kegiatan ini dilaksanakan dalam acara muhadharah setiap jum'at pagi. Melalui observasipenulis melihat kegiatan ini sangat besar pengaruhnya terhadap diri anak dalam rangka pembinaan akhlak mereka, karena di dalam kegiatan ini mereka diberikan santapan rohani dengan ceramah agama. Di samping itu anak juga dapat melatih diri untuk tampil dihadapan teman-

${ }^{44}$ Arifin, GuruMAN I Padang, Wawancara, Padang, 4 Desember 2013

${ }^{45}$ Observasi tentang pembinaan akhlak siswa di MAN 1 Padang, 4 Desember 2013

${ }^{46}$ Armayanti, Guru MAN I Padang, Wawancara, Padang, 4 Desember 2013 
teman mereka. Sehingga mereka di saat berbicara di depan umum tidak merasa ketakutan lagi. ${ }^{47}$

Hal ini juga yang diungkapkan oleh Guru Akidah akhlak : "Dalam rangka menanamkan nilai agama kepada peserta didik, salah satu kegiatan yang telah diprogramkan oleh guru Akidah Akhlak adalah mengadakan kultum setiap jum'at pagi. Kegiatan ini diharapkan bisa menambah pengetahuan agama peserta didik dan dapat juga sebagai sarana latihan bagi mereka untuk bisa tampil di depan khalayak ramai". ${ }^{48}$

4. Upacara Bendera

Hasil wawancara dengan Kepala sekolah mengunkapkan: "Sekolah telah mewajibkan kepada seluruh siswa untuk melaksanakan upacara bendera. Upacara bendera ini diwajibkan sekolah sebagai salah satu cara atau usaha yang dilakukan agar peserta didik terbiasa melaksanakannya dengan disiplin". 49

5. Selalu ikut serta dalam kegiatan keagamaan yang diadakan di sekolah

Hasil wawancara dengansalah seorang guru Akidah Akhlak mengungkapkan: "Keberadaan dan kehadiran guru Akidah Akhlak dan guru yang lainya dalam berbagai kegiatan keagamaan di sekolah sangat diperlukan dalam memotivasi peserta didik agar senantiasa ikut serta dalam memperingati hari yang bersejarah tersebut. Apabila ini bisa diterapkan oleh semua maka ia telah dapat memberikan contoh dan motivasi yang baik kepada peserta didiknya. ${ }^{50}$

Sebagai sikap yang baik guru Akidah Akhlak hendaknya dapat memberikan motivasi dan pengetahuan kepada siswa betapa pentingnya memperingati hari besar agama tersebut. Namun hal itu tentu tidak cukup dilakukan dengan ucapan saja, tetapi ia harus mampu memperlihatkan sikap dengan selalu ikut serta dalam berbagai kegiatan keagamaan.

6. Kerjasama antara majelis guru dan warga sekolah yang lain dalam membina akhlak siswa.

Kerjasama antar warga sekolah merupakan kunci sukses dalam membina akhlak siswa di sekolah, sebagaimana yang diungkapkan oleh salah seorang guru di Madrasyah Aliyah Negeri 1 Padang, bahwa: “Dalam melaksanakan pembinaan akhlak siswa, asas kerjasama selalu diutamakan, karena tidak mungkin kita sebagai manusia biasa mampu mengerjakan setiap

${ }^{47}$ Observasi tentang pembinaan akhlak siswa di MAN 1 Padang, 6 Desember 2013

${ }^{48}$ Fitriyanti, Guru MAN I Padang, Wawancara, Padang, 6 Desember 2013

${ }^{49}$ Marliza, Kepala Sekolah MAN 1 Padang, Wawancara, Padang, 6 Desember 2013

${ }^{50}$ Arifin, Guru MAN I Padang, Wawancara, Padang, 6 Desember 2013 
FITRAH Jurnal Kajian Ilmu-ilmu Keislaman

Vol. 04 No. 2 Desember 2018

program tersebut sendirian, selama saya berada di sekolah ini, yang saya rasakan dan saya alami adalah rasa kekeluargaan dan kerjasama dan saling bantu-membatu selalu terjalin antara sesama guru dan juga pihak sekolah, begitu juga dengan karyawan dalam mensukseskan setiap pembinaan akhlak terhadap siswa". ${ }^{51}$

Informasi yang senada diperoleh dari hasil wawancara dengan guru lain, mengatakan bahwa:" selama saya menjadi guru di MAN 1 Padang yang saya rasakan kekompakan, kerja sama yang baik antara sesama guru-guru, pegawai sekolah dalam membina akhlak siswa. Pembinaan akhlak bukan saja di serahkan kepada guru akidah akhlak atau guru-guru agama lainnya tetapi seluruh guru ikut serta dalam pembinaan akhlak siswa. ${ }^{52}$

Berdasarkan wawancara penulis dengan siswa MAN 1 Padang, mengatakan:"saya melihat guru-guru bekerja sama dalam melakukan pembinaan akhlak,ini terbukti ketika siswa-siswi ada yang melanggar aturan sekolah maka bukan hanya satu guru saja yang memberikan nasehat, tetapi ada kerja sama dalam memberikan nasehat agar siswa-siswi berakhlak baik. ${ }^{53}$

Berdasarkan observasi yang penulis lakukan tentang loyalitas dan kerjasama antar sesama baik guru dengan guru, guru dengan pihak sekolah, guru dengan pihak karyawan dan sebaliknya, terlihat bahwa guru dan warga sekolah lainnya, kerjasama yang antar sesama, hal ini terlihat dari berbagai kegiatan seperti rapat bulanan, mengikuti ibadah harian bersama peserta didik, menghadiri acara kekeluargaan, tanggung jawab membina akhlak peserta didik, semuanya ikut bahu membahu dan bantu membantu, dan tidak ada pertengkaran yang penulis temuai selama penelitian di MAN 1 Padang ini. ${ }^{54}$

\section{Kendala yang Dihadapi Guru Akidah Akhlak dalam Membina Akhlak Siswa di MAN 1 Padang}

Dari hasil wawancara dengan guru Akidah akhlak mengungkapkan : "Kendala yang saya hadapi dalam membina akhlak siswa di MAN 1 Padang adalah tidak ada kerja sama dengan wali murid, lingkungan siswa yang tidak baik dan siswa yang tidak mau mengikuti kegiatan keagamaan". ${ }^{5}$

${ }^{51}$ Fitriyani, Guru MAN I Padang, Wawancara, Padang, 6 Desember 2013

${ }^{52}$ M.Nasir Sarim, Guru MAN I Padang, Wawancara, Padang, 6 Desember 2013

${ }^{53}$ M. Sukri, SiswaMAN I Padang, Wawancara, Padang, 6 Desember 2013

${ }^{54}$ Observasi terhadap pengurus, majelis guru,pegawai MAN 1 Padang, 6 Desember 2013

${ }^{55}$ Fitriyani, Guru MAN I Padang, Wawancara, Padang, 9 Desember 2013 
Hal ini senada dengan diungkapkan oleh guru fiqih mengungkapkan : "Kendala yang saya hadapi dalam membina akhlak siswa di MAN 1 Padang adalah tidak ada kerja sama yang baik dengan wali murid tentang perkembangan kepribadian siswa, pengaruh lingkungan siswa yang tidak mendukung dan kurangnya minat siswa untuk mengikutikegiatan keagamaan" ${ }^{56}$

Menurut guru MAN I Padang bahwa kendala yang dihadapi dalam membina akhlak siswa di MAN 1 Padang adalah: "Rendahnya pendidikan orang tua, sehingga orang tua hanya mengharapkan sekolah dapat merubah terhadap prilaku anaknya maka dengan anggapan itulah maka siswa merasa tidak diperhatikan oleh orang tuanya, sebenarnya terhadap hal ini perlu interaksi antara orang tua dengan guru sehingga keduanya merasa bertanggung jawab dalam perubahan tingkah laku peserta didik". ${ }^{57}$

Beda halnya menurut guru bimbingan konseling bahwa yang menjadi kendala dan hambatan dalam membina akhlak siswa adalah: "Kurang tersedianya waktu khusus untuk pembinaan akhlak dalam arti kata bahwa dalam melakukan pembinaan terhadap tingkah laku siswa hanya sering dilakukan pada proses pembelajaran sedangkan waktu yang khusus untuk melakukan pembinaan terhadap siswa itu tidak tersedia, inilah yang menjadi kendala bagi guru Akidah Akhlak untuk membina akhlak siswa". ${ }^{58}$

Menurut kepala Sekolah kendala lain yang ditemukan dalam membina akhlak siswa adalah: "Siswa salah dalam memilih teman bergaul sehingga siswa yang semula telah mulai berperilaku baik akhirnya terpengaruh untuk berbuat tidak baik. Kebanyakan teman bergaul siswa tersebut adalah yang putus sekolah atau yang terjerumus ke dalam pergaulan bebas. Untuk mengatasi hal tersebut kepala sekolah bekerja sama denga guru Akidah Akhlak dan guru-guru lainnya telah melakukan pengawasan secara ketat dan disiplin dalam pergaulan siswa". ${ }^{59}$

Berdasarkan hasil observasi yang penulis lakukan, kendala yang ditemukan dalam pembinaan akhlak siswa tidak begitu nampak karena berdasarkan observasi yang dilakukan tindakan melanggar peraturan atau ketertiban sekolah langsung dibina dan setelah mendapat bimbingan siswa biasanya akan takut lagi untuk melanggar peraturan yang ada. kendala yang ditemukan adalah Fasilitas tempat shalat tidak memadai seperti mesjid yang kurang besar ruangannya ditambah jumlah peserta didik dari MTsN Durian

\footnotetext{
${ }^{56}$ Arifin, Guru MAN I Padang, Wawancara, Padang, 9 Desember 2013

${ }^{57}$ Armayanti, Guru MAN I Padang, Wawancara, Padang,9 Desember 2013

58 Syahida Hayati, Guru MAN I Padang, Wawancara, Padang, 9 Desember 2013

${ }^{59}$ Marliza, Kepala Sekolah MAN I Padang, Wawancara, Padang, 10 Desember 2013
} 
FITRAH Jurnal Kajian Ilmu-ilmu Keislaman

Vol. 04 No. 2 Desember 2018

Tarung yang secara bersamaan dalam melaksanakan shalat berjamah. Jika seluruh peserta didik dan guru-guru melaksanakan shalat berjamaah, mesjid tidak mampu menampung semuanya secara sekaligus. ${ }^{60}$

Hal ini sesuai dengan apa yang diungkapkan oleh guru Akidah akhlak: "Adapun kendala dalam pembinaan akhlak siswa adalah kurangnya fasilitas yang tersedia seperti masjid yang kurang besar ruangannya sehingga semua siswa tidak bisa melaksanakan shalat berjamaah secara serentak" ${ }^{61}$

Dari hasil wawancara dan observasi yang dilakukan kendala yang dihadapi oleh guru Akidah akhlak dalam membina akhlak siswa adalah tidak ada kerja sama guru dengan wali murid, lingkungan siswa yang tidak baik, sebagaimana siswa yang tidak mau mengikutikesgiatan keagamaan dan siswa salah dalam memilih teman bergaul sehingga siswa yang semula telah mulai berperilaku baik akhirnya terpengaruh untuk berbuat tidak baik. Kebanyakan teman bergaul siswa tersebut adalah anak yang putus sekolah atau yang terjerumus ke dalam pergaulan bebas,serta kurangnya fasilitas yang mendukung terhadap perkembangan siswa seperti tempat ibadah.

\section{Usaha Mengatasi Hambatan yang dihadapi Guru Akidah Akhlak dalam Membina Ahlak Siswa di MAN 1 Padang}

Dalam mengatasi hambatan yang dihadapi guru Akidah Akhlak dalam membina ahlak siswa di MAN 1 Padang berdasarkan dari hasil wawancara dan observasi diketahuilah usaha yang dilakukan antara lain :

1. Kerja sama antara guru Akidah Akhlak dengan kepala Sekolah, majlis guru, orang tua dan pemuka masyarakat.

Sebagaimana yang diungkapkan oleh guru Akidah akhlak : "Dalam pembinaan akhlak siswa ada kerja sama antara guru Akidah Akhlak dengan kepala Sekolah, majlis guru dan orang tua serta pemuka masyarakat karena siswa tidak terlepas dari pihak-pihak tersebut" ${ }^{62}$

2. Melakukan pendekatan secara langsung terhadap siswa.

Seperti yang diungkapkan oleh guru MAN 1 Padang : "Untuk mengatasi hambatan dalam pembinaan akhlak siswa saya melakukan pendekatan terhadap siswa, karena tanpa hal itu saya akan terkendala dalam melakukan pembinaan akhlak mereka". ${ }^{63}$

3. Memberikan nasehat secara berkelanjutan.

${ }^{60}$ Observasi tentang pembinaan akhlak siswa di MAN 1 Padang, 10 Desember 2013

${ }^{61}$ Fitriyani, Guru MAN I Padang, Wawancara, Padang: 10 Desember 2013

${ }^{62}$ Fitriyani, GuruMAN I Padang, Wawancara, Padang, 11 Desember 2013

${ }^{63}$ Armayanti, Guru MAN I Padang, Wawancara, Padang, 11 Desember 2013 
Guru akidah akhlak dalam hal ini mengatakan : "Untuk mengatasi hambatan dalam pembinaan akhlak siswa, maka guru jangan pernah bosan dalam memberikan nasehat terhadap siswa". ${ }^{64}$

hhhhhh ${ }^{65}$

\section{PENUTUP}

Setelah memperhatikan apa yang telah diuraikan dari hasil penelitian ini, mengenai upaya guru Akidah akhlak dalam membina akhlak siswa di MAN 1 Padang. Maka dapat penulis simpulkan sebagai berikut :

Upaya pembinaan akhlak di dalam kelas yang sudah dilakukan berupa pembinaan secara teoritis, pendekatan keteladanan, melarang siswa mencontek ketika ujian, pendekatan nasihat dan memberikan sangsi atau hukuman yang mendidik kepada siswa yang bersalah.

Upaya pembinaan akhlak di luar kelas yang sudah dilakukan berupa keteladanan, shalat zuhur berjamaah, kultum setiap jum'at pagi, selalu ikut serta dalam kegiatan keagamaan yang ada di sekolah.

Kendala yang dihadapi dalam membina akhlak siswa adalah kurangnya kerja sama dengan orang tua siswa, lingkungan siswa yang tidak baik, masih adanya siswa yang tidak mau mengikuti kegiatan keagamaan, rendahnya pendidikan orang tua, kurang tersedianya waktu yang khusus untuk pembinaan akhlak, adanya diantara yang siswa salah dalam memilih teman bergaul dan kurangnya fasilitas ibadah.

Usaha dalam mengatasi hambatan dalam membina akhlak siswa adalah kerja sama antara guru Akidah Akhlak dengan Kepala Sekolah, majlis guru, orang tua dan pemuka masyarakat, melakukan pendekatan secara langsung terhadap siswa, memberikan nasehat secara berkelanjutan.

${ }^{64}$ Arifin, Guru MAN I Padang, Wawancara, Padang, 11 Desember 2013

${ }^{65}$ Zainal Hidayat, Upaya guru akidah akhlak dalam membina akhlak siswa di MTS Ma'arif Sabilull Hudaa Bogor, Laporan PenelitiaN, FITK UIN Syarif Hidayatullah Jakarta. tt. 
FITRAH Jurnal Kajian Ilmu-ilmu Keislaman

Vol. 04 No. 2 Desember 2018

\section{DAFTAR PUSTAKA}

\section{BUKU}

Ariga, Selamat. "Pendidikan Akhlak Anak Dalam Keluarga Pedagang Di Kelurahan Dadok Tunggul Hitam Kecematan Koto Tangah." Tesis Sarjana Pendidikan, PPs IAIN Imam Bonjol Padang, 2010.

Arikunto, Suharsimi. Prosedur Penelitian: Suatu Pendekatan Praktik. Jakarta: Rineka Cipta, 2013.

Departemen Agama. Direktorat Jenderal Pendidikan Islam. Undang-undang Republik Indonesia Nomor 14 Tahun 2005 tentang Guru dan Dosen. Bandung: Citra Umbara, 2006. https://books.google.co.id/books?id=87DFmgEACAAJ\&dq=Undangundang+RI+No.14+Tahun+2005+Tentang+Guru+dan+Dosen\&hl=en\&sa=X \&ved=0ahUKEwiT8dekqM7fAhXadCsKHcS6CI4Q6AEIKTAA.

LN, H. Syamsu Yusuf. Psikologi perkembangan anak \& remaja. Bandung: Remaja Rosdakarya, 2000. https://books.google.co.id/books?id=kaEAAAACAAJ\&dq=Syamsu+Yusuf+LN\&hl=en\&sa=X\&ved=0ahUKEwibyOi tqc7fAhUOaI8KHQtmDPIQ6AEILDAA.

Moleong, Lexy J. Metodelogi Penelitan Kualitatif. Bandung: Remaja Rosdakarya, 2000.

Nata, Abudin. Metodologi Studi Islam. Jakarta: Raja Grapindo Persada, 2004.

Rusn, Abidin Ibnu. Pemikiran Al-Ghazali tentang pendidikan. Yogyakarta: Pustaka Pelajar, 1998. https://books.google.co.id/books?id=bp5HAgAACAAJ\&dq=Abidin+lbnu+ Rusd,+Pemikiran+AlGhazali+Tentang+Pendidikan\&hl=en\&sa=X\&ved=0ahUKEwjCkbX9qM7f AhWJMI8KHZ5GB5AQ6AEIKzAA.

Sukmadinata, Nana Syaodih. Metode penelitian pendidikan. Bandung: Program Pascasarjana Universitas Pendidikan Indonesia dengan PT Remaja Rosdakarya, 2005. https://books.google.co.id/books?id=qXxjAQAACAAJ\&dq=Nana+Syaodi $\mathrm{h}+$ Sukmadinata,+Metodologi+Penelitian+Pendidikan\&hl=en\&sa=X\&ved= 0ahUKEwjC7qzjrM7fAhUaWX0KHY-1AgkQ6AEIKTAA.

Tafsir, Ahmad. Metodologi pengajaran agama Islam. Bandung: Remaja Rosdakarya, 1999. 
VUAgAACAAJ\&dq=Ahmad+Tafsir.+Metodologi+Pengajaran+Agama\&hl $=$ en\&sa=X\&ved=0ahUKEwi19pGJq87fAhUFqY8KHSeoAYMQ6AEIKTAA

Yulian, Dewi. “Usaha Pembinaan Akhlak Siswa Di Smp Negeri 2 Pada." Tesis Sarjana Pendidikan, PPs IAIN Imam Bonjol Padang, 2013.

\section{DAFTAR WAWANCARA}

Arifin, Guru MAN I Padang, Wawancara, Padang, 3 Desember 2013

-------, Guru MAN I Padang, Wawancara, Padang, 4 Desember 2013

-------, Guru MAN I Padang, Wawancara, Padang, 6 Desember 2013

-------, Guru MAN I Padang, Wawancara, Padang, 9 Desember 2013

--------, Guru MAN I Padang, Wawancara, Padang, 11 Desember 2013

Armayanti, Guru MAN I Padang, Wawancara, Padang, 3 Desember 2013

-------, Guru MAN I Padang, Wawancara, Padang, 4 Desember 2013

--------, Guru MAN I Padang, Wawancara, Padang, 11 Desember 2013

-------, Guru MAN I Padang, Wawancara, Padang, 9 Desember 2013

-------, Guru MAN I Padang, Wawancara, Padang, 29 November 2013

--------, Guru MAN I Padang, Wawancara, Padang, 3 Desember 2013

-------, GuruMAN I Padang, Wawancara, Padang, 4 Desember 2013

--------, Guru MAN I Padang, Wawancara, Padang, 6 Desember 2013

--------, Guru MAN I Padang, Wawancara, Padang, 9 Desember 2013

-------, Guru MAN I Padang, Wawancara, Padang: 10 Desember 2013

-------, Guru MAN I Padang, Wawancara, Padang, 11 Desember 2013

M. Nasir Sarim, Guru MAN I Padang, Wawancara, Padang, 29 November 2013

--------, Guru MAN 1 Padang, wawancara, Padang 3 Desember 2013

--------, Guru MAN I Padang, Wawancara, Padang, 6 Desember 2013

Marliza, Kepala sekolah MAN I Padang, Wawancara, Padang, 29 November 2013

-------, Kepala sekolah MAN I Padang, Wawancara, Padang, 30 November 2013 
FITRAH Jurnal Kajian Ilmu-ilmu Keislaman

Vol. 04 No. 2 Desember 2018

--------, kepala MAN 1 Padang, wawancara, Padang, 3 Desember 2013

--------, Kepala Sekolah MAN 1 Padang, Wawancara, Padang, 6 Desember 2013

--------, Kepala Sekolah MAN I Padang, Wawancara, Padang, 10 Desember 2013

Muhammad Sukri, siswa MAN 1 Padang, wawamcara,29 November 2013

--------, siswa MAN 1 Padang, wawancara, Padang, 3 Desember 2013

--------, Siswa MAN I Padang, Wawancara, Padang, 6 Desember 2013

Muharni, Guru MAN 1 Padang, Wawancara, Padang, 3 Desember 2013

Suci Pramita, siswa MAN 1 Padang, wawancara, Padang, 3 Desember 2013

--------, siswa MAN 1 Padang, wawancara, Padang, 4 Desember 2013

Syahida Hayati, Guru MAN I Padang 